\title{
Changing Trends of Shopping Habits and Tourism During the Second Wave of COVID-19 - International Comparison
}

\author{
Renáta Machová \\ J. Selye University, Faculty of Economics and Informatics, Komárno, Slovakia \\ Enikő Korcsmáros \\ J. Selye University, Faculty of Economics and Informatics, Komárno, Slovakia \\ Monika Esseová \\ J. Selye University, Faculty of Economics and Informatics, Komárno, Slovakia \\ Roland Marča \\ J. Selye University, Faculty of Economics and Informatics, Komárno, Slovakia
}

Received: 12 April 2021. Revision received: 15 May 2021. Accepted: 24 May 2021

\begin{abstract}
Over the last year, many things have changed in every field as a consequence of the COVID-19 pandemic. Given the rapid spread of the coronavirus, the heads of states and governments had to respond to the virus forthwith. As government restrictions have been introduced, people started to reconsider their decisions in terms of consumption and saving. The closures affected many areas that changed people's daily lives. As a result, new trends have appeared, for instance, in the tourism field and people's shopping habits. The data were collected among Slovak and Hungarian citizens through surveys as a quantitative method. Nonparametric Pearson's chi-square test, Spearman's rho correlation test, and Mann-Whitney $\mathrm{U}$ tests were performed to analyze six formulated hypotheses. For the latter, it was necessary to carry out normality tests. The main purpose of this article is to give an international comparison in questions whether people will prefer domestic tourism over foreign one if people prefer domestic traders' products or foreign traders' products, whether the respondents buy online more frequently due to the pandemic, if they spend less on leisure travel and whether they think that the interest in e-commerce continues to grow. As a result of the research, it can be declared that both Slovak and Hungarian people traders prefer buying domestic traders' products instead of foreign traders' ones, while the Hungarian respondents shop online more frequently. The results pointed out that Slovak respondents will prefer domestic tourism over foreign tourism.
\end{abstract}

Key Words: pandemic, e-commerce, new trends, tourism

JEL Classification: E21, L83, Z32

Reference: Machová, R., Korcsmáros, E., Esseová, M., Marča R. (2021). Changing Trends of Shopping Habits and Tourism During the Second Wave of COVID-19 - International Comparison. Journal of Tourism and Services, 22(12), 131-149. doi: 10.29036/jots.v12i22.256

\section{Introduction}

One of the most important questions today is what trends can be expected as a result of the coronavirus and in which areas will be significant changes. While new trends emerged, others intensified in many fields worldwide. As a result of the pandemic, people have more time to completely rethink their travel habits (Stankov et al., 2020). It means that people will plausibly pay more attention to the ecological, economic, and environmental background of the journey. 


\section{JOURNAL OF TOURISM AND SERVICES}

Issue 22, volume 12, ISSN 1804-5650 (Online)

www.jots.cz

The highly affected tourism industry needs to be restarted and reorganized urgently with the help of new strategies which focus on the new consumer trends (Lew et al., 2020; Sharma et al., 2021). Moreover, not only the mentioned industry but also the global economy and political system will accommodate to the changes (Sharma et al., 2021). The seriousness of the crisis has caused serious difficulties to the economies of millions of households. It may take a long time for leisure travels to reset to the pre-pandemic level (Ioannides \& Gyimóthy, 2020).

The increasing worth of new digital technologies within cities gives a reason to develop the industry at several destinations. As a result, numerous new destinations appear, which sharpens the competition between and within regions (Horita, 2017; Salama \& Oláh, 2019; Chebli et al., 2020). Nevertheless, cities have to plan different tourism strategies to intensify strategic positioning (Chebli et al., 2020).

There is a large number of studies that examine the consequences of the current pandemic on the global economy and tourism industry, but only a limited amount of them analyse the impact of COVID-19 on travel habits focusing on localism. It is especially valid for the chosen countries, considering that they do not belong to the most popular tourist destination in Europe, despite the fact that there are plenty of heritages. Nonetheless, tourism plays an important role in Hungary's GDP. For this reason, the important question is what changes can be expected in the tourism industry, as the number of tourists has greatly decreased due to the pandemic. A question is will people prefer domestic tourism over foreign tourism in the future? Whether Will people prefer domestic traders' products or foreign traders' products? Besides, we find it interesting to examine what new trends are presumably emerging in terms of shopping habits due to closures and moving companies to the online space as a consequence of the coronavirus. Thus, we can state that this study contributes to the mentioned research gap as we examined the expected trends in tourism and shopping habits in Slovakia and Hungary. Central European countries have a similar culture, so we assume that the results can not only explore the expected trends in tourism in these two countries but can also provide clues for the countries around them.

The structure of the paper is the following: the second part deals with the appropriate literature reviews on the local and foreign levels. The following part describes the research method, sampling, and data collection and clarifies the used statistical tests. It justifies the measurement level of the variables and the reason for choosing the given tests. The fourth section includes the received results than the discussion where we compared the results with other studies. The conclusion part includes the main findings of the research, the limitations, and the directions for further research.

\section{Literature review}

The coronavirus epidemic has affected people in different ways, which is well reflected in their reactions. Based on Szabo et al.'s (2020) research, Hungarian women, mainly among young adults, view the COVID-19 crisis from a different perspective as men because the women considered themselves more stressed. As we see, the main reason for that can be that many young people work alongside their university studies to cover their costs. Furthermore, the tourism and hospitality industries employ workers mainly from youth.

Tourism plays an important role in employment, wealth, and recreation. Worldwide more than 319 million jobs are related to the tourism industry, which means $10 \%$ of total employment (Avgeli et al., 2020). The Ministry of Finance of the Slovak Republic (2020) predicted in their report 88,000 jobs lost, mainly in the tourism, hospitality, transport, and manufacturing industries for 2020. In contrast to that, 207184 unemployed were registered in December of 2020 and 135517 unemployed in 2019. It means that more than 71,000 people lost their job in the last year. According to this, the prediction did not come true, but unfortunately, the number of unemployed seems to rise further in the coming months (ŠÚSR, 2021) (ŠÚSR, 2020a). 


\section{JOURNAL OF TOURISM AND SERVICES}

Issue 22, volume 12, ISSN 1804-5650 (Online)

www.jots.cz

As claimed by Donthu and Gustafsson (2020), due to the physical distancing and rapid spread of digitalisation, we can expect some fundamental changes in consumers' behaviour. People who lost their jobs because of the coronavirus outbreak and introduced restrictions will try to retrain themselves and earn new skills in order to find another job. As a result, some people will pick up new habits in shopping, sports, the use of technological tools, migration, and also tourism.

Due to the high level of digitalisation, there have appeared new alternatives in the analysed industry. Thanks to this new possibilities came up which offer job opportunities for underqualified people also. Thus, it is highly recommended to use social platforms to strengthen the bond between local retailers and consumers (Santos et al., 2020).

During the COVID-19 pandemic, people are willing for impulsive buying as they buy goods that are believed to help to prevent getting infected by coronavirus disease (Naeem, 2020).

The current pandemic situation has had a significant impact on the business world. Companies were already competing with the online stores and the ensuing pandemic only exacerbates the difficulties. As a result, most of the physical stores will either go out of business or permanently close. This means that consumers will not be able to return to their previous shopping habits (Eger et al., 2021). In the tourism industry, there operate plenty of SMEs. Therefore, one of the main issues was how they adapt their businesses to the current situation. As claimed by Haywood, (2020) SMEs are in a completely vulnerable situation, thus they need urgent help to survive the economic crisis.

Many stores, catering units have been closed in many countries across Europe, and much of the sales have been transferred to the online space. Furthermore, restrictions also contributed to the change in the consumer basket. In general, there has been an increase in demand for sustainable foods, vitamins, sports equipment, IT equipment, and gardening, among other things. It can be observed that the frequency of purchases decreased, especially during the first wave. In contrast, the number of purchased products increased due to accumulation and on the other hand more people cook at home. At the same time, the number of food orders increased significantly.

Due to the rapid spread of coronavirus, the amount spent on daily consumer goods has drastically increased. Presumably, the daily spendings have almost reached 70-100 billion HUF in Hungary. The increase and consumption of food products can be explained by working from home and lockdown (Veres, 2020).

Due to the sudden increase in demand, food prices have also risen, which significantly affects shopping habits (Chenarides et al., 2020).

There are four factors causing panic buying due to the coronavirus which are the following: perception, being afraid of the unknown, social psychology, coping/adaptive behaviour. The panic buying appears when people try to minimise the risk of an unknown situation and protect themselves from the consequences of it. To adapt their behaviour to the situation, they try to be prepared for the worst-case scenarios (Yuen et al., 2020; Loxton et al., 2020).

Myriad consumers have adjusted their shopping habits to shop in safe circumstances to avoid the risk of getting infected. A study has shown that $77 \%$ of retail customers will pay more attention to cleanliness and safety while shopping (Blakely, 2020; Untaru \& Han, 2021).

In consequence of the unforeseeable impacts and duration of COVID-19, we can report about stockpiling behaviour among people worldwide. Due to the restrictions, many shops were opened for limited hours, which contributed to an increase in demand for alternative distribution channels (Eger et al., 2021).

According to the restaurant closures, it is likely that they will face problems with re-opening. Some of them are allowed to stay open for takeaway services but they can report only a small revenue which does not cover the costs (Gössling - Scott - Hall, 2020).

A number of strategies are available for online sellers who would like to persuade people to buy online despite the fact that there exist more cons. It is vital for them to find solutions to their hesitations 


\section{JOURNAL OF TOURISM AND SERVICES}

Issue 22, volume 12, ISSN 1804-5650 (Online)

www.jots.cz

like improving the quality of the product or the availability of customer service. It is essential to build consumer trust intending to increase sales (Daroch et al., 2021).

Based on Elrhim's and Elsayed's (2020) research, the COVID-19 pandemic affected the global ecommerce market in many ways, like their returns or stock prices. According to Jílková and Králová (2021), Baby Boomers played a significant role in the e-commerce growth during the second wave of COVID-19. They found out that $43 \%$ of all their respondents purchased online since the pandemic had appeared. The pre-pandemic distribution of this statement was $12 \%$.

The impact of the sharing economy on e-commerce is becoming increasingly important as the system provides access to goods, services, and data, so users have access to the resources when they need them (Ključnikov et al., 2018; Almeida et al., 2019).

As a consequence of the COVID-19 crisis, it is evident that many businesses are not able to sustain themselves without help which leads to providing loans and debts from national and local governments, as it is also their interest to help them (Humphries et al., 2020; Hu et al., 2021). We can state that business circumstances have been changing on a daily basis since the coronavirus appeared. Due to this, it is hard to make predictions about which strategies will help businesses to earn profits despite the closures. According to Daroch et al. (2021), people have different experiences while shopping via the internet. Consumers face various problems while they buy things from e-shops. Based on their research, six factors influence consumers' behaviour towards buying from online sites. The following factors influence people's online shopping intentions in a negative way: fear of bank transactions, inconvenience, bad reputation, negative experience, insufficient product information, and lack of trust.

Furthermore, theatres and other cultural institutions can benefit from digital technologies as they contribute to the popularisation of local culture and heritage since they launched virtual exhibitions and guided tours (Kang \& Yang, 2020; Bec et al., 2021). In contrast to these trends, Li et al. (2018) formulated the term "digital-free tourism" which refers to those spaces where people do not have either internet connection or mobile signals. We hold the view that during the pandemic the digitalisation has come to the fore and in the last few months, people have spent a lot of time in their homes. As a result, in the coming months, the demand for those destinations which represent the digital-free tourism principle can rapidly increase. According to Baum and Hai (2020) it is worth mentioning that the visitation to relatives and friends have a big proportion of travel numbers.

Businesses don't spend enough time on consumers' feedback and opinion. Given the myriad of negative experiences and the lack of trust towards businesses, they should make an effort in their popularization. There exist a lot of methods for how they could do that. First of all, businesses should focus on buyer's feedback, and according to them, they should make some plans on how they could increase people's willingness to buy from them.

In order to develop the tourism industry, local shop owners must take care of the tourists' satisfaction because it has economic and socio-cultural impacts on the country (Çelik, 2019).

Nowadays the emotional feedback of customers is playing a foremost role in business marketing (Sarwari, 2017).

Next to the growing demand for e-commerce, there can be changing trends in how people relate to traders' products. People might consider domestic traders' products safer, whether they buy foreign traders' products mainly because of their lowest price.

Many people make a mistake when they think that domestic products are more expensive than foreign ones. There are a lot of benefits to buying from local traders. For instance, it is much more likely that local foods are fresh and don't consist of preservatives, therefore they are much healthier. A large number of researchers and business people presume a new trend named localism as a consequence of coronavirus. Given the hard economic situation, amidst people was created cooperation in order to support local businesses and traders. It could be considered as a mainstream movement as people buy food rather from the local market instead of imported ones. 


\section{JOURNAL OF TOURISM AND SERVICES}

Issue 22, volume 12, ISSN 1804-5650 (Online)

www.jots.cz

Promoting tourism contributes to improving local awareness of national heritages. First and foremost, it has a huge impact on a country's GDP, and on the other hand, it is relevant in terms of job creation (Sarvašová \& Királ'ová, 2018). As claimed by Sheth (2020), there exists an universal law related to consumers' behaviour. It means that when people give up on an activity or a necessity, it usually comes back as a hobby. According to this pandemic situation, people who buy less will come back to shopping as a hobby. We consider it as a rightful assumption because many people, mainly youth, and women miss this activity due to the closures. Besides, a large number of people visit the opened markets for two reasons: support local communities, and they want to be among people because they miss the social interactions.

Besides the impact of coronavirus on shopping habits, it caused fundamental changes also in many other fields over the world.

The international tourist arrivals decreased in March 2020 since it was $-57 \%$. In terms of the number of tourists decreased, Europe is in 2nd place as it reached -60\% in March 2020 (UNTWO, 2020; Păvăluc et al., 2020).

Tourism and migration are relevant for many countries because of the impact on economies. Due to the strict travel restrictions, countries have to face a sharp reduction in the tourism field. As people can't travel beyond the borders, they stay at home, or they make domestic trips (ILO, 2021).

We considered it important to describe the effects of the COVID-19 pandemic on fields like tourism. It is important to mention that the economies of the V4 countries have been suffering a lot due to the coronavirus and government restrictions. Due to this, it is relevant for all four countries to focus on their own tourism industry by making strategic plans about how to restart tourism in order to generate income as soon as possible and recover from the economic crisis. Working through social media channels, making an effort to public relations as well as bringing together regional strengths to attract more tourists can be a fairly simple but effective way (Antošová - Vogl - Schraud, 2020). It is essential to pay attention to tourist feedback because negative online reviews are more likely to be read than positive ones (Atabay - Çizel, 2020; Lee et al., 2017). Some experts believe that with the use of technologies the tourism field could be reactivated. Thanks to technology businesses can build their marketing strategy according to the consumers' needs and as a result, local tourism will be supported (Villacé-Molinero et al., 2021).

The precautions include border crossing conditions which have been tightened and closing the catering and tourism units. As a result, many people have lost their jobs. Therefore, the short- and longterm subsidies and the development of strategies are relevant for the revitalization of tourism.

During the time of the pandemic, the small number of investors and low values of capital invested can contribute to systematic risk in terms of available investment funds. It means that for investors it will be risky in the coming years to invest in fields that have faced an economic crisis (Zinecker et al., 2021). The tourism field is relevant for both Slovakia and Hungary because it can largely affect their competitiveness, and as a result, the countries' economic situation too (Gavurova et al., 2020).

According to the global crisis, we can perceive a significant slowdown of the global economy. Due to this, the COVID-19 pandemic has a negative impact on Slovakia's and Hungary's economy too. Looking forward there may be a sharp decline in their revenues mainly in tourism and transport (Government of Hungary, 2020). The decline will be spectacular as 2019 was relatively a successful year for both countries due to the previous years. Slovakia's international tourism receipts were 2,843 million euros, and the number of arrivals was 15,4 million in 2019 (Knoema, 2020a). Hungary's international tourism receipts were 8,649 and the number of arrivals was 61.4 million in 2019 (Knoema, 2020b).

According to Mura and Ključnikov (2018), Slovak rural tourism will develop in the next few years. This was stated before the outbreak of the COVID-19 pandemic but it can be considered valid because according to the restrictions the demand for local tourism will continue to grow. The profitability of the tourism industry mainly depends on the qualified workforce as they are highly experienced and qualified in their field (Belas et al., 2020; Sardo et al., 2018). The micromobilities at tourism could be more popular 


\section{JOURNAL OF TOURISM AND SERVICES}

Issue 22, volume 12, ISSN 1804-5650 (Online)

www.jots.cz

if the public transport would be developed enough. The policies should make an effort on building infrastructure to extend the possibilities of walking and cycling (Davies - Blazejewski - Sherriff, 2020). The tourists are willing to discover something new and to explore various cultures and places. Regarding this, people tend to travel hundreds of kilometers in order to visit new places (Dzurov Vargová et al., 2020).

Likewise, to the localism in consumption of food, we can presume localism also in tourism for many reasons. One of them could be that people feel safe in their mother country more than in a foreign country. Furthermore, during the lockdown, people can travel mainly between the borders. Consequently, people have found out how many beautiful places are in their mother country. According to the new habits, we predict a post-pandemic trend towards localism as many other researchers.

\section{Methods}

The purpose of this study is to seek information about the preference of domestic trips over foreign ones, and the preference for domestic traders, and the expected trends in the tourism industry in the shadow of COVID-19 according to the Hungarian and Slovak respondents and provide an international comparison of two countries. In regard to the expected trends, we aimed to ascertain the reconsideration of shopping habits, whether the respondents shop online more frequently, if they spend less on leisure travel and whether they think that the interest in e-commerce continues to grow. In the case of H3 - H6 we assumed that the Hungarian respondents have the greater willingness for the analysed trend as closures had a bigger impact on Hungary's economy because of it's tourism is more relevant according to the number of visitors. In regard to, we noticed more TV campaigns in Hungarian TV advertisements which encouraged people to stay at home, and avoid close contact with others, we assumed that the Hungarian respondents' interest in e-commerce is more dominant.

The examined groups of the questionnaire survey were Slovak and Hungarian citizens. We chose as a research method, cross-sectional method, which means that we took a single sample of the elements of the population once. The required data were collected from 862 respondents, of which $40.37 \%$ was received from the Hungarian and 59.63\% from the Slovak respondents. As a result, $54.03 \%$ of the Hungarian respondents were women and $45.97 \%$ men. Whereas, $50.77 \%$ of the Slovak respondents were women and 49.23\% men. The data collection was performed between January 2021 and March 2021. The survey included 24 closed questions from which we used 10 questions to examine our aims. To carry out the study, we used an online and paper-based form of survey.

According to Wiley (1999), with the help of sample size calculation, we need to ascertain the optimum sample size to evaluate the population prevalence with great precision. For this purpose, we used the following formula:

$$
n=\frac{Z^{2} \mathrm{P}(1-\mathrm{P})}{d^{2}}
$$

where $\mathrm{n}=$ sample size $=15190136$ according to ŠÚSR (2020b) and KSH (2021), critical value at $95 \%$ confidence level, $\mathrm{Z}=1.96, \mathrm{P}=$ expected prevalence or proportion $=40 \%=0.4$, and $\mathrm{d}=$ precision $=5 \%=0.05$. Therefore, a size of 369 respondents could be adequate for deriving meaningful inference in our research. According to the obtained sample size value, we can state that our research sample is representative.

During the research, we formulated six hypotheses.

In the practical part of the research, the following hypotheses were examined:

H0: There is no significant relationship between those respondents who attended at least 5 foreign trips in 2019 and their preference for domestic tourism over foreign tourism in the future.

H1: There is a significant relationship between those respondents who attended at least 5 foreign trips in 2019 and their preference for domestic tourism over foreign tourism in the future. 


\section{JOURNAL OF TOURISM AND SERVICES}

Issue 22, volume 12, ISSN 1804-5650 (Online)

www.jots.cz

Based on Walker and Ugoni (1995), in this case, the variables can be measured on a nominal measurement level, so we performed Pearson's chi-square test. In the hypothesis test, the number of foreign trips is an independent variable, and the preference of domestic tourism over foreign tourism is a dependent variable. In the former variable, we defined two categories whereas, within the latter variable we defined three categories which can be seen in Table 1 . The contingency table shows the combined distribution of the two examined variables, which was expanded by the relative frequency by rows. According to McHugh (2013), all the conditions pertain to our data. The observations must be independent, so none of the responses can appear in more than one cell at a time. Therefore, the expected value in a maximum of $20 \%$ of the cells can be less than five. We met both of the requirements. We determined a $5 \%$ significance level which means that there is a $5 \%$ chance that we reject the null hypothesis.

HO: There is no significant relationship between the change in shopping habits due to the coronavirus and the preference of domestic traders' products over foreign traders' products.

H2: There is a significant relationship between the change in shopping habits due to the coronavirus and the preference of domestic traders' products over foreign traders' products.

According to UCLA Statistical Consulting Group (n.d.), in this case, the variables can be measured on an ordinal scale, so we performed Spearman's rank correlation test, which measures the strength and direction of association between two ranked variables. In the hypothesis test, the change in shopping habits is an independent variable, and the preference of domestic traders' products over foreign traders' products is a dependent variable.

With the next four formulated hypotheses we analysed the coming trends in the shadow of COVID-19. HO: The Hungarian respondents are not more willing to reconsider their shopping habits in the future.

H3: The Hungarian respondents are more willing to reconsider their shopping habits in the future.

H0: The Hungarian respondents are not more willing to shop online more frequently.

H4: The Hungarian respondents are more willing to shop online more frequently.

HO: The Hungarian respondents are not more willing to spend less on leisure travel.

H5: The Hungarian respondents are more willing to spend less on leisure travel.

H0: Hungarian respondents are not more willing to have the opinion that interest in e-commerce continues to grow.

H6: Hungarian respondents are more willing to have the opinion that interest in e-commerce continues to grow.

For these four hypotheses, a test of normality was carried out for four hypotheses. Based on Aslam (2019), for this purpose, the Kolmogorov-Smirnov test was used to examine if scores are likely to follow some distribution in the analysed groups.

According to Artaya (2019), if the value of asymptotic sig is less than 0.05 then the analysed population is not normally distributed, whereas it's greater than 0.05 the population is normally distributed.

According to Refugio and Delmo (2018), in the case of non-normal distribution, the nonparametric Mann-Whitney test is used to determine the significant differences between an ordinal dependent variable and a dichotomous independent variable.

\section{Results}

In the following part, we examined the first hypothesis that we have formulated.

Table 1. Number of foreign trips * Preference for domestic tourism over foreign tourism Crosstabulation - Slovakia

\begin{tabular}{|l|l|l|l|}
\hline \multirow{2}{*}{} & \multicolumn{3}{|c|}{$\begin{array}{c}\text { Preference for domestic } \\
\text { tourism over foreign tourism }\end{array}$} \\
\cline { 2 - 3 } & Yes & No & $\begin{array}{c}\text { Not } \\
\text { decided }\end{array}$ \\
\hline
\end{tabular}




\section{JOURNAL OF TOURISM AND SERVICES}

Issue 22, volume 12, ISSN 1804-5650 (Online)

www.jots.cz

\begin{tabular}{|c|c|c|c|c|c|c|}
\hline \multirow{8}{*}{$\begin{array}{l}\text { Number of } \\
\text { foreign } \\
\text { trips }\end{array}$} & \multirow[t]{4}{*}{ 6-10 times } & Count & 40 & 104 & 6 & 150 \\
\hline & & Expected Count & 35.1 & 104.6 & 10.2 & 150.0 \\
\hline & & $\begin{array}{l}\% \text { within Number } \\
\text { of foreign trips }\end{array}$ & $26.7 \%$ & $69.3 \%$ & $4.0 \%$ & $100.0 \%$ \\
\hline & & Adjusted Residual & 1.8 & -.2 & -2.7 & \\
\hline & \multirow{4}{*}{$\begin{array}{l}\text { More than } \\
10 \text { times }\end{array}$} & Count & 8 & 39 & 8 & 55 \\
\hline & & Expected Count & 12.9 & 38.4 & 3.8 & 55.0 \\
\hline & & $\begin{array}{l}\% \text { within Number } \\
\text { of foreign trips }\end{array}$ & $14.5 \%$ & $70.9 \%$ & $14.5 \%$ & $100.0 \%$ \\
\hline & & Adjusted Residual & -1.8 & .2 & 2.7 & \\
\hline \multirow{3}{*}{\multicolumn{2}{|c|}{ Total }} & Count & 48 & 143 & 14 & 205 \\
\hline & & Expected Count & 48.0 & 143.0 & 14.0 & 205.0 \\
\hline & & $\begin{array}{l}\% \text { within Number } \\
\text { of foreign trips }\end{array}$ & $23.4 \%$ & $69.8 \%$ & $6.8 \%$ & $100.0 \%$ \\
\hline
\end{tabular}

Source: own editing based on primary data collection

Table 2. Number of foreign trips $*$ Preference for domestic tourism over foreign tourism Crosstabulation - Hungary

\begin{tabular}{|c|c|c|c|c|c|c|}
\hline & \multicolumn{3}{|c|}{$\begin{array}{l}\text { Preference for domestic } \\
\text { tourism over foreign tourism }\end{array}$} & \multirow{2}{*}{ Total } \\
\hline & & & Yes & No & $\begin{array}{c}\text { Not } \\
\text { decided }\end{array}$ & \\
\hline \multirow{8}{*}{$\begin{array}{l}\text { Number of } \\
\text { foreign trips }\end{array}$} & \multirow[t]{4}{*}{ 6-10 times } & Count & 8 & 66 & 12 & 86 \\
\hline & & Expected Count & 10.7 & 63.3 & 12.0 & 86.0 \\
\hline & & $\begin{array}{l}\% \text { within } \\
\text { Number of } \\
\text { foreign trips }\end{array}$ & $9.3 \%$ & $76.7 \%$ & $14.0 \%$ & $\begin{array}{r}100.0 \\
\%\end{array}$ \\
\hline & & Adjusted Residual & -1.5 & 1.1 & .0 & \\
\hline & \multirow{4}{*}{$\begin{array}{l}\text { More than } \\
10 \text { times }\end{array}$} & Count & 8 & 29 & 6 & 43 \\
\hline & & Expected Count & 5.3 & 31.7 & 6.0 & 43.0 \\
\hline & & $\begin{array}{l}\% \text { within } \\
\text { Number of } \\
\text { foreign trips }\end{array}$ & $\begin{array}{r}18.6 \\
\%\end{array}$ & $67.4 \%$ & $14.0 \%$ & $\begin{array}{r}100.0 \\
\%\end{array}$ \\
\hline & & Adjusted Residual & 1.5 & -1.1 & .0 & \\
\hline \multirow{3}{*}{\multicolumn{2}{|c|}{ Total }} & Count & 16 & 95 & 18 & 129 \\
\hline & & Expected Count & 16.0 & 95.0 & 18.0 & 129.0 \\
\hline & & $\begin{array}{l}\% \text { within } \\
\text { Number of } \\
\text { foreign trips }\end{array}$ & $\begin{array}{r}12.4 \\
\%\end{array}$ & $73.6 \%$ & $14.0 \%$ & $\begin{array}{r}100.0 \\
\%\end{array}$ \\
\hline
\end{tabular}

Source: own editing based on primary data collection 


\section{JOURNAL OF TOURISM AND SERVICES}

Issue 22, volume 12, ISSN 1804-5650 (Online)

www.jots.cz

The values written in the contingency tables above are not sufficient to describe the relationship between the two variables, so we performed the chi-square test.

The following table includes the values of Pearson's chi-square test according to the answers from the respondents from Slovakia and Hungary.

Table 3. Chi-square test - number of foreign trips and preference for domestic tourism over foreign tourism

\begin{tabular}{|l|r|r|c|r|r|}
\hline & $\begin{array}{c}\text { Value - } \\
\text { SK }\end{array}$ & $\begin{array}{c}\text { Value } \\
- \text { HU }\end{array}$ & df & $\begin{array}{c}\text { Asymptotic Sig. } \\
\text { (2-sided) - SVK }\end{array}$ & $\begin{array}{c}\text { Asymptotic Sig. (2- } \\
\text { sided) - HUN }\end{array}$ \\
\hline Pearson Chi-Square & 19.605 & 2.337 & 2 & .011 & .311 \\
\hline Likelihood Ratio & 17.388 & 2.226 & 2 & .000 & .329 \\
\hline Linear-by-Linear & 13.164 & .935 & 1 & .000 & .334 \\
\hline N of Valid Cases & 205 & 129 & & & \\
\hline
\end{tabular}

After performing the test, it can be stated that in the case of Slovakia, there is a significant relationship between the two variables, as the significance level is $p=0.011$. In the case of Hungary, there is no significant relationship between the two examined variables, as the significance level is $\mathrm{p}=$ $0.311>0.05$. In the case of Slovakia, we examined the Cramer V coefficient, which is suitable for characterizing the closeness of the relationship between two nominal variables.

Table 4. Cramer V coefficient

\begin{tabular}{|l|l|r|r|}
\hline \multicolumn{2}{|c|}{} & \multicolumn{1}{|c|}{$\begin{array}{c}\text { Value } \\
\text { (Slovakia) }\end{array}$} & $\begin{array}{c}\text { Approximate } \\
\text { Significance - } \\
\text { SK }\end{array}$ \\
\hline $\begin{array}{l}\text { Nominal by } \\
\text { Nominal }\end{array}$ & Phi & .211 & .011 \\
\cline { 2 - 4 } & Cramer's V & .211 & .011 \\
\hline \multicolumn{2}{|l|}{ N of Valid Cases } & 205 & \\
\hline
\end{tabular}

Source: own editing based on primary data collection

The value of the Cramer $\mathrm{V}$ coefficient is 0.211 , so the relationship can be characterized by moderate strength according to IBM (n.d.). Based on the obtained results, in the case of Slovakia, we reject the null hypothesis, while in the case of Hungary, we fail to reject the null hypothesis.

In the following part, we examined the second hypothesis that we have formulated. During the analysis, we examined the relationship between two variables.

Table 5. Spearman's rank correlation

\begin{tabular}{|c|c|c|c|c|c|c|}
\hline & & & $\begin{array}{l}\text { Change } \\
\text { in } \\
\text { shoppi } \\
\text { ng } \\
\text { habits - } \\
\text { SVK }\end{array}$ & $\begin{array}{l}\text { Preference } \\
\text { for } \\
\text { domestic } \\
\text { traders' } \\
\text { products - } \\
\text { SVK }\end{array}$ & $\begin{array}{l}\text { Change } \\
\text { in } \\
\text { shoppi } \\
\text { ng } \\
\text { habits - } \\
\text { HUN }\end{array}$ & $\begin{array}{l}\text { Preference } \\
\text { for } \\
\text { domestic } \\
\text { traders' } \\
\text { products - } \\
\text { HUN }\end{array}$ \\
\hline \multirow[t]{2}{*}{$\begin{array}{l}\text { Spearman' } \\
\text { s rho }\end{array}$} & \multirow{2}{*}{$\begin{array}{l}\text { Change } \\
\text { in } \\
\text { shopping }\end{array}$} & $\begin{array}{l}\text { Correlation } \\
\text { Coefficient }\end{array}$ & 1.000 & .355 & 1.000 & .350 \\
\hline & & Sig. (2-tailed) & & .000. & & .000 \\
\hline
\end{tabular}




\section{JOURNAL OF TOURISM AND SERVICES}

Issue 22, volume 12, ISSN 1804-5650 (Online)

www.jots.cz

\begin{tabular}{|l|l|l|r|r|r|r|}
\hline & habits & $\mathrm{N}$ & 514 & 514 & 348 & 348 \\
\cline { 2 - 6 } & \begin{tabular}{l} 
Preferen \\
ce for \\
\multirow{2}{*}{$\begin{array}{l}\text { domestic } \\
\text { traders' }\end{array}$}
\end{tabular} & $\begin{array}{l}\text { Correlation } \\
\text { Coefficient }\end{array}$ & .355 & 1.000 & .350 & 1.000 \\
\cline { 2 - 7 } & Sig. (2-tailed) & .000 & 514 & 514 & 348 & 348 \\
\cline { 2 - 7 } & & & & & .000 &. \\
\hline
\end{tabular}

Source: own editing based on primary data collection

After performing the test, it can be said that in the case of Slovakia, there is a significant relationship between the two variables, as the significance level is $\mathrm{p}<0.001$, and the rho $=0.355$, which indicates a positive, moderate strength relationship according to Dancey and Reidy (2004). In the case of Hungary, there is also a significant relationship between the two variables, as the significance level is $\mathrm{p}$ $<0.001$ and rho $=0.350$, which means a positive, moderate relationship. Based on the obtained results, we fail to reject the null hypothesis for both countries.

The following two tables (see Table 6 and Table 7) contain the results of normality test for four hypotheses for Slovakia and Hungary.

Table 6. Test of Normality (Hungary)

\begin{tabular}{|l|r|r|c|}
\hline \multirow{2}{*}{} & \multicolumn{3}{|c|}{ Kolmogorov-Smirnov } \\
\cline { 2 - 4 } & Statistic & \multicolumn{1}{|c|}{$\mathrm{df}$} & \multicolumn{1}{c|}{ Sig. } \\
\hline I will reconsider my shopping & .213 & 348 & .000 \\
\hline I shop online more frequently & .229 & 348 & .000 \\
\hline I spend less on leisure travel & .419 & 348 & .000 \\
\hline Interest in online commerce continues to grow & .304 & 348 & .000 \\
\hline
\end{tabular}

Source: own editing based on primary data collection

Table 7. Test of Normality (Slovakia)

\begin{tabular}{|l|r|r|r|}
\hline \multirow{2}{*}{} & \multicolumn{3}{|c|}{ Kolmogorov-Smirnov } \\
\cline { 2 - 4 } & Statistic & \multicolumn{1}{c|}{$\mathrm{df}$} & \multicolumn{1}{c|}{ Sig. } \\
\hline I will reconsider my shopping & .272 & 514 & .000 \\
\hline I shop online more frequently & .268 & 514 & .000 \\
\hline I spend less on leisure travel & .388 & 514 & .000 \\
\hline Interest in online commerce continues to grow & .314 & 514 & .000 \\
\hline
\end{tabular}

Source: own editing based on primary data collection

The Kolmogorov-Smirnov test indicated that all the examined dependent variables follow a non-normal distribution.

Our third hypothesis is the following: The Hungarian respondents are more willing to reconsider their shopping habits in the future.

Table 8. Ranks 


\section{JOURNAL OF TOURISM AND SERVICES}

Issue 22, volume 12, ISSN 1804-5650 (Online)

www.jots.cz

\begin{tabular}{|l|l|l|r|r|}
\hline & Country & \multicolumn{1}{|c|}{ N } & Mean Rank & Sum of Ranks \\
\hline \multirow{3}{*}{ I will reconsider my shopping } & Slovakia & 514 & 421.30 & 216548.00 \\
\cline { 2 - 5 } & Hungary & 348 & 446.57 & 155405.00 \\
\cline { 2 - 5 } & Total & 862 & & \\
\hline
\end{tabular}

Source: own editing based on primary data collection

The Table 8 indicates that the Hungarian group had a little higher value of Mean Rank. For this reason, it is worth examining if the Hungarian respondents' willingness is significantly greater than Slovak respondents or not.

Table 9. Test Statistics $\mathbf{- H 3}$

\begin{tabular}{|l|r|}
\hline & I will reconsider my shopping \\
\hline Mann-Whitney U & 84193.000 \\
\hline Wilcoxon W & 216548.000 \\
\hline Z & -1.515 \\
\hline Asymp. Sig. (2-tailed) & .130 \\
\hline
\end{tabular}

Source: own editing based on primary data collection

The Mann-Whitney test indicated that Hungarian respondents $(M d n=4)$ willingness to change their shopping habits in the future was not significantly greater than Slovak respondents $(\mathrm{Mdn}=3), \mathrm{U}=$ $84193.0 \mathrm{Z}=-1.515 \mathrm{p}=0.065$ (1-tailed) as we devided the 2 -tailed value by 2 because we assumed the greater willingness for one group.

Our fourth hypothesis is the following: The Hungarian respondents are more willing to shop online more frequently. Based on the previous results and literature we performed the following hypotheses analyses.

Table 10. Ranks

\begin{tabular}{|l|l|l|r|r|}
\hline & Country & N & Mean Rank & \multicolumn{1}{|c|}{ Sum of Ranks } \\
\hline \multirow{3}{*}{ I shop online more frequently } & Slovakia & 514 & 399.25 & 205216.00 \\
\cline { 2 - 5 } & Hungary & 348 & 479.13 & 166737.00 \\
\cline { 2 - 5 } & Total & 862 & & \\
\cline { 2 - 5 } & Hon & & & \\
\hline
\end{tabular}

Source: own editing based on primary data collection

Table 10 indicates that the Hungarian group had a higher value of Mean Rank. Thereby it is important to figure out if the Hungarian respondents' willingness is significantly greater than Slovak respondents or not.

Table 11. Test Statistics $\mathbf{- H 4}$

\begin{tabular}{|l|r|}
\hline & I shop online more frequently \\
\hline Mann-Whitney U & 72861.000 \\
\hline Wilcoxon W & 205216.000 \\
\hline
\end{tabular}




\section{JOURNAL OF TOURISM AND SERVICES}

Issue 22, volume 12, ISSN 1804-5650 (Online)

www.jots.cz

\begin{tabular}{|l|r|}
\hline Z & -4.863 \\
\hline Asymp. Sig. (2-tailed) & .000 \\
\hline
\end{tabular}

Source: own editing based on primary data collection

The Mann-Whitney test indicated that Hungarian respondents $(\mathrm{Mdn}=2)$ willingness to shop online more frequently was significantly greater than Slovak respondents $(\mathrm{Mdn}=2), \mathrm{U}=72861.0 \mathrm{Z}=-4.863 \mathrm{p}<$ 0.001 (1-tailed) as we divided the 2 -tailed value by 2 because we assumed the greater willingness for one group. It is necessary to calculate the effect size. Based on Rosenthal (1994). The effect size can be calculated by dividing the absolute value of $\mathrm{Z}$ by the square root of the sample size, so we use the following formula: $r=\mathrm{Z} / \sqrt{ } \mathrm{N}$. The effect size is 0.165 , which can be characterized as a small effect according to Cohen (1988).

Our fifth hypothesis is the following: Hungarian respondents are more willing to spend less on leisure travel.

\section{Table 12. Ranks}

\begin{tabular}{|l|l|l|r|r|}
\hline & Country & N & Mean Rank & Sum of Ranks \\
\hline \multirow{3}{*}{ I spend less on leisure travel } & Slovakia & 514 & 422.39 & 217111.00 \\
\cline { 2 - 5 } & Hungary & 348 & 444.95 & 154842.00 \\
\cline { 2 - 5 } & Total & 862 & & \\
\hline
\end{tabular}

Source: own editing based on primary data collection

Table 12 indicates that Hungarian respondents group had a little higher value of Mean Rank. Hence, it is important to figure out if the Hungarian respondents significantly spend less on leisure travel or not.

Table 13. Test Statistics - H5

\begin{tabular}{|l|r|}
\hline & I spend less on leisure travel \\
\hline Mann-Whitney U & 84756.000 \\
\hline Wilcoxon W & 217111.000 \\
\hline Z & -1.622 \\
\hline Asymp. Sig. (2-tailed) & .105 \\
\hline
\end{tabular}

Source: own editing based on primary data collection

The Mann-Whitney test demonstrated that Hungarian respondents $(\mathrm{Mdn}=5)$ significantly do not spend less on leisure travel than Slovak respondents ( $M d n=5), U=84756.0 Z=-1.622 p=0.0525$ (1-tailed) as we devided the 2 -tailed value by 2 because we assumed the greater willingness for one group.

Our sixth hypothesis is the following: The Hungarian respondents are more willing to have the opinion that the interest in e-commerce continues to grow.

Table 14. Ranks

\begin{tabular}{|l|l|l|l|l|}
\hline & Country & N & Mean Rank & Sum of Ranks \\
\hline
\end{tabular}




\section{JOURNAL OF TOURISM AND SERVICES}

Issue 22, volume 12, ISSN 1804-5650 (Online)

www.jots.cz

\begin{tabular}{|l|l|l|l|l|}
\hline \multirow{2}{*}{$\begin{array}{l}\text { Interest in online commerce } \\
\text { continues to grow }\end{array}$} & Slovakia & 514 & 429.07 & 220540.00 \\
\cline { 2 - 5 } & Hungary & 348 & 435.09 & 151413.00 \\
\cline { 2 - 5 } & Total & 862 & & \\
\hline
\end{tabular}

Source: own editing based on primary data collection

Table 14 illustrates that the Hungarian group had a little higher value of Mean Rank. Thus, it is worth examining if the Hungarian respondents are more of that opinion that interest in e-commerce continues to grow.

Table 14. Test Statistics - H6

\begin{tabular}{|l|r|}
\hline & Interest in online commerce continues to grow \\
\hline Mann-Whitney U & 88185.000 \\
\hline Wilcoxon W & 220540.000 \\
\hline Z & -.370 \\
\hline Asymp. Sig. (2-tailed) & .711 \\
\hline
\end{tabular}

Source: own editing based on primary data collection

The Mann-Whitney test demonstrated that Hungarian respondents $(\mathrm{Mdn}=4)$ are not more willing to have the opinion that interest in e-commerce continues to grow than Slovak respondents $(\mathrm{Mdn}=4), \mathrm{U}$ $=88185.0 \mathrm{Z}=-0.370 \mathrm{p}=0.355$ (1-tailed) as we devided the 2 -tailed value by 2 because we assumed the greater willingness for one group.

\section{Discussion}

Based on the obtained results we can state that those Slovak respondents who attended at least 5 foreign trips in 2019 will prefer domestic tourism over foreign tourism in the future. On the other hand, in the case of Hungarian respondents, it cannot be stated.

As a consequence of the new pandemic, tourists may prefer domestic trips over foreign ones in order to support the domestic economy. It could lead to ethnocentrism considering the fact that people's behaviour has changed a lot (Kock et al., 2019; Zenker \& Kock, 2020) Based on Molinero et al.'s (2021). international research, the tourism industry needs to restarts urgently, especially for those countries whose economy was significantly affected by the closures and restrictions. They state that it is highly recommended to find a balance between the desire for travel and the possible risk during the activity. They hold the likewise view as many other experts that technology plays an important role in reactivating the tourism industry. Moreover, they highlight that with the help of technology, businesses can provide more customer-specialized offers which increases the power of local tourism.

Regarding the shopping habits, we didn't obtain among Hungarian respondents' greater willingness to reconsider their shopping habits in the future. We hold the view that this result can be a consequence of panic buying (Yuen et al., 2020; Loxton et al., 2020) which was discussed in more detail in the theoretical part of the research.

Our point of view is that businesses should focus on making strategies in order to moderate the effects of the crisis. As we can see in the frequencies of online shopping, many businesses turned to ecommerce, which helped them to survive. We hold the view that businesses should take advantage of the changing habits in tourism and make plans to attract local tourism to support the domestic economy as many people will return to travel habits. It would be vital to convince people to avoid panic buying and 


\section{JOURNAL OF TOURISM AND SERVICES}

Issue 22, volume 12, ISSN 1804-5650 (Online)

www.jots.cz

overshopping due to the pandemic. As claimed by Sealy (2020), in order to be prepared for a likewise crisis, it is worth planning different scenarios. They should include best-case and worst-case scenarios also. Planning ensures businesses prepare for unforeseen situations such as economic crises and increased demand. In the case of businesses, it is first and foremost to set up short-term reserves to cover fixed expenses and salaries. The scenarios should also contain plans for innovation, development, and sustainability.

It is a complex task to predict future trends because it could be quite difficult to recognise and prepare for the new consumer needs affected by the COVID-19 pandemic. Despite these, it is vital for businesses to be well-prepared for arduous situations (Zhai, Zhong, \& Luo, 2019; Pappas, 2021). As a result of unpreparedness, companies may face a myriad of problems. According to Matijová et al., (2019), that's why it is essential to increase Slovakia's long-term competitiveness in the tourism industry, it is key to strengthen it from various sides and to be up-to-date to current consumer needs and new trends.

\section{Conclusion}

The results of the examination proved that the Hungarian respondents are more willing to purchase online more frequently. Behind this trend could be the previously mentioned TV campaigns and advertisements which persuaded many people to stay at home and avoid crowded places and if it's possible, then purchase things online.

The outcomes showed that Hungarian respondents don't spend less on leisure travel than Slovak respondents. Plausibly, it can be traced back to the fact that the travel restrictions in Hungary were not as strict as in Slovakia. The findings declared that many Slovak people will prefer domestic trips over foreign ones in the future. We assume this trend as a consequence of the fear of being infected with the COVID-19. Furthermore, we found out that both countries' respondents will prefer domestic traders' products over foreign traders' products. During the pandemic, households are more deliberated in their shopping habits, so savings are more dominant. Despite that, it is clear to almost all people that this situation is causing serious problems for most households. Due to that, many people decided to help people and buy food from domestic traders rather than from foreign ones. Besides, a large number of people consider local products safer than those which are imported. We assume that these results predict the localism trend which is supported by other experts.

In spite of the fact that Hungarian respondents shop online more frequently, they don't think that the increased number of online purchasing continues to grow. This assumption could be right regarding the increased number of orders which led to a decrease in quality. Besides, people cannot try the dress on, check their quality, and control whether the product works right. Moreover, many people like walking between the rows of shops. This type of pleasure is missing during online shopping.

Regarding the economic side of losses due to pandemic, it is important to mention that inflation was significantly affected by changes in demand, mainly due to changes in fuel prices and the preference for domestic tourism over foreign tourism. The latter was characterized by rising prices, as well as rising inflation in the short run. As demand and prices fall, inflation may decline too, but in the next period, it is quite likely that the inflation may remain fluctuated. It is clear for almost all people that this situation is causing serious problems for most people. Due to that, many people try to help others who found themselves in a hard situation. In the case of households, we suggest them to reconsider their consumption and savings, and if they have a chance to support local traders who are in a bad economic situation, help them with buying products from them.

It is important to acknowledge some limitations which can serve as a basis for further research. We analysed whether the income of the respondents has decreased or not and whether they spend less on leisure travel. We found out that in many cases the income of the respondents had decreased and they spent less money on leisure travel ever since the pandemic began. In future research, it would be relevant 


\section{JOURNAL OF TOURISM AND SERVICES}

Issue 22, volume 12, ISSN 1804-5650 (Online)

www.jots.cz

to analyse how much their discretionary income decreased during the pandemic, which people usually spend on materials and experiences which contribute to their happiness.

In the theoretical part of the research, we mentioned that due to the rapid spread of digitalisation, future travel destinations will plausibly change. Moreover, according to Zenker and Kock (2020), thanks to the rapid spread of pandemic the existing images of destination goals can easily change over a short period of time. One of the main reasons is the high infection rate. Therefore, it would be worth examining the possible destinations that people would like to visit after the pandemic and whether digital free tourism will come to the fore or not.

Considering the limitations of this study, they could form the basis for further research and could contribute to filling the gap in this research theme. Furthermore, it would be worth extending the research to V4 countries as they have a very similar culture, and also examine the post-pandemic trends including the impacts of COVID-19 on the tourism industry from an economic side and compare it with the prepandemic data.

\section{References}

1. Antošová, G., Vogl, M., \& Schraud M. (2020). Challenges for the Visegrad Group - The Coronavirus Crises and its Impact on Tourism. Visegrad Journal on Bioeconomy and Sustainable Development. 9(1). 28-32. https://content.sciendo.com/view/journals/vjbsd/9/1/article-p28.xml

2. Artaya, P, I. (2019).Kolmogorov-Smirnov Test. Qualitative Research Analysis Method. DOI:10.13140/RG.2.2.31867.36642

3. Aslam, M. (2019). Introducing Kolmogorov-Smirnov Tests under Uncertainty: An Application to Radioctive Data. ACS Omega. 5(1). DOI: 10.1021/acsomega.9b03940

4. Atabay, I., \& Çizel, B. (2020). Comparative content analysis of hotel reviews by mass tourism destination. Journal of Tourism and Services. 21(11). 147-166. DOI: 10.29036/jots.v11i21.163

5. Avgeli, V., Bakir, A., Dahlan M., \& Wickens, E. (2020). 4IR Impacts on Tourism Education and Industry. Journal on Tourism \& Sustainability, 4(1), 6-15.

6. Baum, T., \& Hai, N, T, T. (2020). Hospitality, tourism, human rights and the impact of COVID19. International Journal of Contemporary Hospitality Management. 32(7). 23972407. https://doi.org/10.1108/IJCHM-03-2020-0242

7. Belas, J., Amoah, J., Petráková Z., Kljuchnikava, Y., \& Bilan, Y. (2020). Selected Factors of SMEs Management in the Service Sector. Journal of Tourism and Services. 21(11). 129-146. DOI: https://doi.org/10.29036/jots.v11i21.215

8. Blakely, F. (2020). The Urgency of Real-Time Communication \& Contactless Experiences. Medallia Zingle.

9. Çelik, S. (2019). Does Tourism Change Tourist Attitudes (Prejudice and Stereotype) towards Local People? Journal of Tourism and Services. 10(18). 35-46. https://doi.org/ 10.29036/jots.v10i18.89

10. Chebli, A., Foued, S, B., \& Meriem, C. (2020). Market Segmentation in Urban Tourism: Exploring the Influence of Personal Factors on Tourists' Perception. Journal of Tourism and Services, 20(11), 74-108. DOI:10.29036/jots.v11i20.144

11. Chenarides, L., Grebitus, C., Lusk, L, J., \& Printezis, I. (2020). Food consumption behavior during the COVID-19 pandemic. Agribusiness. 37(1). https://doi.org/10.1002/agr.21679

12. Cohen, J. (1988). Statistical Power Anaysis for the Behavioral Sciences (2nd ed.). Hillsdale, NJ: Lawrence Erlbaum Associates, Publishers.

13. Dancey, C., \& Reidy, J. (2004). Statistics without maths for psychology: using SPSS for windows. Prentice-Hall. 


\section{JOURNAL OF TOURISM AND SERVICES}

Issue 22, volume 12, ISSN 1804-5650 (Online)

www.jots.cz

14. Daroch, B., Nagrath, G., \& Gupta, A. (2020). A study on factors limiting online shopping behaviour of consumers. Rajagiri Management Journal. 14 https://www.emerald.com/insight/content/doi/10.1108/RAMJ-07-2020-0038/full/html

15. Davies, N., Blazejewski, L., \& Sherriff, G. (2020). The rise of micromobilities at tourism destinations. Journal of Tourism Futures. 6 (3). 209-212. DOI: https://doi.org/10.1108/JTF-102019-0113

16. Donthu, N., \& Gustafsson, A. (2020). Effects of COVID-19 on business and research. Journal of Business Research. 117. 284-289. https://doi.org/10.1016/j.jbusres.2020.06.008

17. Dzurov, V, T., Gallo, P., Švedová, M., Litavcová, E., \& Košíková, M. (2020). Non-Traditional forms of tourism in Slovakia as a concept of competitiveness. GeoJournal of Tourism and Geosites. 30(2). 801-807. DOI: 10.30892/gtg.302spl04-508

18. Eger, L., Komárková, L., Egerová, D., \& Mičík, M. (2021). The effect of COVID-19 on consumer shopping behaviour: Generational cohort perspective. Journal of Retailing and Consumer Services. 61. DOI: https://doi.org/10.1016/j.jretconser.2021.102542

19. Elrhim, A., \& Elsayed, A. (2020). The Effect of COVID-19 Spread on the e-commerce market: The case of the 5 largest e-commerce companies in the world. SSRN Electronic Journal. DOI: http://dx.doi.org/10.2139/ssrn.3621166

20. Gavurova, B., Ivankova, V., Rigelsky, M., \& Prívařová, M. (2020). Relations between tourism spending and global competitiveness: an empirical study in developed OECD countries. Journal of Tourism and Services. 21(11). 38-54. DOI: 10.29036/jots.v11i21.175

21. Government of Hungary. (2020). Convergence programme of Hungary 2020-2024: report. Slovakia: Government of Hungary, 88 p.

22. Gössling, S., Scott, D., \& Hall, M, C. (2020). Pandemics, tourism and global change: a rapid assessment of COVID-19. Journal of Sustainable Tourism. 29. 1-20. DOI: https://doi.org/10.1080/09669582.2020.1758708

23. Haywood, M, K. (2020). A post COVID-19 future - tourism re-imagined and re-enabled. Tourism Geographies. 599-609. https://doi.org/10.1080/14616688.2020.1762120

24. Horita, Y. (2018). Urban Development and Tourism in Japanese Cities. Tourism Planning \& Development, 15, 26-39.

25. Humphries, J, E., Neilson, C., \& Ulyssea, G. (2020). The evolving impacts of COVID-19 on small businesses since the CARES act. Discussion Paper 2230 Cowles Foundation (2020).

26. IBM. (n.d.). Cramér-féle $V$ együttható. https://www.ibm.com/docs/hu/cognosanalytics $/ 11.1 .0$ ?topic $=$ terms-cramrs-v\&fbclid $=I w A R 1 \mathrm{dZj}$-zryqeGoduJU4WlpH3vQ_wl-

Am_YQfdzm2eMK-wCRL5ECHEeEaQYs

27. ILO. (2021). COVID-19 and the world of work: report. Switzerland: International Labour Organization, $35 \mathrm{p}$.

28. Ioannides, D., \& Gyimóthy, SZ. (2020). The COVID-19 as an opportunity for escaping the unsustainable global tourism path. Tourism Geographies. 22(3). 624-632. https://doi.org/10.1080/14616688.2020.1763445

29. Jílková, P., \& Králová, P. (2021). Digital Consumer Behaviour and eCommerce Trends during the COVID-19 Crisis. International Advances in Economic Research, 1-3. https://doi.org/10.1007/s11294-021-09817-4

30. Kang, Y., \& Yang, K, C. (2020). Employing digital reality technologies in art extibitions and museums: A global survey of best practices and implications. Virtual and Augmented Reality in Education, Art and Museums. 139-161. DOI: 10.4018/978-1-7998-1796-3.ch008

31. Ključnikov, A., Krajč́k, V., \& Vincúrová, Z. (2018). International Sharing Economy: the Case of AirBnB in the Czech Republic. Economics and Sociology, 11(2), 126-137. doi:10.14254/2071789X.2018/11-2/9 


\section{JOURNAL OF TOURISM AND SERVICES}

Issue 22, volume 12, ISSN 1804-5650 (Online)

www.jots.cz

32. Knoema. (2020a). Slovakia - International tourism receipts. Retrieved from: https://knoema.com/atlas/Slovakia/Tourism-receipts

33. Knoema. (2020b). International tourism receipts in Hungary. Retrieved from https://knoema.com/data/hungary+receipts +international-tourism?unit=currentprices $\% 20$ us-dollars

34. Kock, F., Josiassen, A., Assaf, A. G., Karpen, I., \& Farrelly, F. (2019). Tourism ethnocentrism and its effects on tourist and resident behavior. Journal of Travel Research. 58(3), 427-439. https://doi.org/10.1177/0047287518755504

35. KSH. (2021). A népesség száma, január 1. report. Hungary: Központi Statisztikai Hivatal. http://www.ksh.hu/

36. Lew, A, A., Cheer, J, M., Haywood, M., Brounder, P., \& Salazar, N, B. (2020). Visions of travel and tourism after the global COVID-19 transformation of 2020. Tourism Geographies. doi: 10.1080/14616688.2020.1770326

37. Li, J., Pearce, L, P, \& Low, D. (2018). Media representation of digital-free tourism: A critical $\begin{array}{lllll}\text { discourse } & \text { analysis. } & \text { Tourism }\end{array}$ https://doi.org/10.1016/j.tourman.2018.06.027

38. Matijová, M., Onuferová, E., Rigelský, M., \& Stanko, V. (2019). Impact of Selected Indicators of Tourism Capacity and Performance in the Context of the Unemployment Rate in Slovakia. Journal of Tourism and Services. 10(19). 1-23. https://doi.org/10.29036/jots.v10i19.95

39. McHugh, M, L. (2013). The Chi square test of independence. Biochemia Medica. 23(2). 143-149.

40. Ministry of Finance of the Slovak Republic. (2020). Stability Programme of the Slovak Republic for 2020 to 2023: report. Slovakia: Ministry of Finance of the Slovak Republic. 53.

41. Molinero, V, T., Fernández, M, J, J., Orea, A, G., \& Fuentes, L, M. (2021). Understanding the new post-COVID-19 risk scenario: Outlooks and challenges for a new era of tourism. Tourism Management. DOI: https://doi.org/10.1016/j.tourman.2021.104324

42. Mura, L., \& Ključnikov, A. (2018). Small Businesses in Rural Tourism and Agrotourism: Study from Slovakia. Economics and Sociology. 11(3). 286-300. DOI: 10.14254/2071-789X.2018/11-3/17

43. Naeem, M. (2020). Understanding the customer psychology of impulse buying during COVID19 pandemic: implications for retailers. International Journal of Retail \& Distribution Management. DOI: doi:10.1108/ijrdm-08-2020-0317

44. Păvăluc, C., Brînză, G., Anichiti, A., \& Butnaru, I. G. (2020). COVID-19 pandemic and its effects on the tourism sector. CES Working Papers, 12(2), 111-122.

45. Refugio, C., \& Delmo, E, J. (2018). Empirical Research on Mann-Whitney U-test. Statistics Class Projects. DOI:10.13140/RG.2.2.11899.36649

46. Santos, A, M., González, M, C., Haegeman, K., \& Rainoldi, A. (2020). Behavioural changes in tourism in times of COVID-19. (Report No. JRC121262). Publications Office of the European Union. doi: $10.2760 / 00411$

47. Sarvašová, I., \& Királ'ová, A. (2018). Educational Tourism in Arboretum -The Case of Borová Hora. Journal of Tourism and Services. 9(16). 31-44. https://doi.org/10.29036/jots.v9i16.53

48. Sarwari, S. (2017). Relationship Marketing Model - The Practice of Relationship between Hoteliers and Loyal Customers of Five Star Hotels in Bangladesh. Journal of Tourism and Services. 9(16). 27-44. DOI: 10.29036.2017.8.15.3

49. Sealy, W. (2020). A Commentary on Risk and Resilience in the Hospitality, Tourism, Aviation and Events Industry: Responses to COVID - 19 and Lessons Learned. Journal on Tourism \& Sustainability, 4(1), 82-93.

50. Sharma, G, D., Thomas, A., \& Paul, J. (2021). Reviving tourism industry post-COVID-19: A resilience-based framework. Tour Manag Perspect. doi: 10.1016/j.tmp.2020.100786 


\section{JOURNAL OF TOURISM AND SERVICES}

Issue 22, volume 12, ISSN 1804-5650 (Online)

www.jots.cz

51. Sheth, J. (2020). Impact of Covid-19 on consumer behavior: Will the old habits return or die?. Journal of Business Research. 117. 280-283. https://doi.org/10.1016/j.jbusres.2020.05.059

52. ŠÚSR. (2020a). Štatistická ročenka regiónov Slovenska: report. Slovakia: Štatistický úrad Slovenskej republiky, $434 \mathrm{p}$.

53. ŠÚSR. (2020b). Stav obyvatelistva v SR k. 30.júnu 2020. report. Slovakia: Štatistický úrad Slovenskej republiky. Stav obyvatel'stva v SR k 30. júnu 2020 (statistics.sk)

54. ŠÚSR. (2021). Nezamestnanost' - mesačné śtatistiky. Available on the internet: https://www.upsvr.gov.sk/statistiky/nezamestnanost-mesacnestatistiky/2020.html?page_id=971502

55. Stankov, U., Filimonau, V., \& Vujičić, D, M. (2020). A mindful shift: an opportunity for mindfulness-driven tourism in a post-pandemic world. Tourism Geographies. 22(3). 703-712. https://doi.org/10.1080/14616688.2020.1768432

56. Szabo, A., Ábel, K., \& Boros, S. (2020). Attitudes toward COVID-19 and stress levels in Hungary: Effects of age, perceived health status, and gender. Psychological Trauma: Theory, Research, Practice, and Policy. 12(6). 572-575. http://dx.doi.org/10.1037/tra0000665

57. UCLA, Statistical Consulting Group (n.d.). Choosing the Correct Statistical Test in SAS, STATA, SPSS and R. https://stats.idre.ucla.edu/other/mult-pkg/whatstat/

58. Veres, P. (2020). A napi fogyasztási cikkek vásárlási szokásainak vizsgálata a koronavírus-járvány idején. Globális kihivás-Lokális válaszok, A koronavirus (COVID-19) gaz̨dasági és társadalmi összefüggései és hatásai. 115-141.

59. Walker, B. F., \& Ugoni, A. (1995). The Chi square test: an introduction. COMSIG Review, 4(3), 61-64.

60. Wiley, W, D. (1999). Biostatistics: A Foundation for Analysis in the Health Sciences. 7th edition. New York: John Wiley \& sons.

61. Yuen, K, F., Wang, X., Ma, F., \& Li, K, X. (2020). The Psychological Causes of Panic Buying Following a Health Crisis. International Journal of Environmental Research and Public Health. 17(10). https://doi.org/10.3390/ijerph17103513

62. Zenker, S., \& Kock, F. (2020). The coronavirus pandemic - A critical discussion of a tourism research agenda. Tourism Management. 86. https://doi.org/10.1016/j.tourman.2020.104164

63. Zhai, X., Zhong, D., \& Luo, Q. (2019). Turn it around in crisis communication: An ABM approach. Annals of Tourism Research. 79, https://doi.org/10.1016/j.annals.2019.102807

64. Zinecker, M., Skalicka, M., Balcerzak, A, P., \& Pietrzak, M. B. (2021). Business angels in the Czech Republic: characteristics and a classification with policy implications. Economic ResearchEkonomska Istraživanja. DOI: 10.1080/1331677X.2021.1890179

\section{Brief description of Author/Authors:}

\section{Dr. habil. Ing. Renáta Machová, PhD.}

ORCID ID: https://orcid.org/0000-0002-7817-0187

Department of Management, Faculty of Economics and Informatics, Associate Professor, Hradná 167/21, P.O.Box 54, Komárno, Slovakia, machovar@,ujs.sk. Long-time expert from practice in the area of entrepreneurship and employment policy, in the context of small and medium-sized enterprises. Expert with experience in the business sphere enabling the theoretical knowledge to be actively coupled with practical skills of future managers. Actually she focuses on the exploration of different habitst of different generations. 
PhDr. Enikő Korcsmáros, PhD.

ORCID ID: https://orcid.org/0000-0002-2026-8712

Department of Economics, Faculty of Economics and Informatics, Assistant Professor, Hradná 167/21, P.O.Box 54, Komárno, Slovakia, korcsmarose@, ujs.sk. She is an expert who focuses her attention on research into barriers to entrepreneurship, analyzes the impact of negative business phenomena. Her research focuses on the challenges of SMEs in the era of industry 4.0 from a different point of view.

\section{Bc. Monika Esseová}

ORCID ID: https://orcid.org/0000-0002-6727-8889

Department of Management, Faculty of Economics and Informatics, Student, Hradná 167/21, P.O.Box 54, Komárno, Slovakia, 124392@,student.ujs.sk. Her research interests are consumer behaviour and tourism.

\section{Roland Marča}

ORCID ID: https://orcid.org/0000-0003-4556-366X

Department of Economics, Faculty of Economics and Informatics, Student, Hradná 167/21, P.O.Box 54, Komárno, Slovakia, 126410@student.ujs.sk. His research interests are consumer behaviour and tourism. 